\title{
METAFÍSICA E METAPSICOLOGIA EM CONFRONTO: Aristóteles e Lacan no Seminário VII
}

\author{
Metaphysics and Metapsychology in \\ confrontation: Aristotle and Lacan in Seminar VII
}

Vincenzo di Matteo

Doutor em Filosofia e Docente da Universidade Federal de Pernambuco. Atualmente é Prof.

Adjunto IV da Universidade Federal de Pernambuco e Membro de corpo editorial da Perspectiva Filosófica. e-mail: dimatteo@npd.com.br

\begin{abstract}
Resumo
Neste artigo, pretendo retomar a crítica à metafísica em nome dmetapsicologia psicanalítica; registrar, especificamente, a confrontação operada por Lacan (Seminário VII. A ética da psicanálise) entre ética aristotélica e psicanalítica, com destaque para os temas da felicidade, do sumo bem, do desejo e do prazer; situar e compreender os diferentes referenciais antropológicometafísicos que legitimam as duas reflexões éticas; mostrar os dois "jogos de linguagem" que devem ser respeitados em sua autonomia e diferença. A confrontação não visa necessariamente emitir um julgamento de valor quanto à verdade de uma ou outra concepção, e sim compreender os problemas e as respectivas soluções propostas por Aristóteles, em seu tempo, e a psicanálise lacaniana, no nosso.
\end{abstract}

Palavras-chave: Metafísica; Metapsicologia; Ética; Aristóteles; Lacan. 


\section{Abstract}

In this paper I intend to take again the criticism to metaphysics in the name of psychoanalytical metapsychology. At the same time, I try to point out specifically the confrontation between aristotelian ethics and psychoanalytical ethics according to Lacan (Seminar VII. The ethics of psychoanalysis) and put in relief themes such as happiness, summum bonun, will and pleasure, as well as to situate and understand the different anthropological and metaphysical system of references where both ethic reflexions are legitimated, showing also the two plays of words which should be respected on their own autonomy and difference. The confrontation has not the intention to emit a sense of value in regard to the truth in respect of one or other conception, but to comprehend the problems and the respective solutions proposed by Aristotle, in his time, and the Lacan's psychoanalysis, in our time.

Keywords: Metaphysics; Metapsychology; Ethics; Aristotle; Lacan.

Outros defeitos da minha natureza sem dúvida me entristeceram e me fizeram sentir-me humilde; com a metafísica é diferente: não só não tenho nenhum talento, mas tampouco nenhum respeito por ela.

Em segredo - não se pode dizer estas coisas em voz alta creio que um dia a metafísica será condenada como uma praga, como um mau uso do pensamento, como uma sobrevivência do período da Weltanschauung religiosa.

(Carta de 30.1.1927. FREUD, 1982).

Esse trecho de uma carta de Freud ao Professor de Filosofia Werner Achelis já é suficiente para evidenciar as tensas relações existentes entre o fundador da psicanálise e a filosofia entendida como metafísica. Na ocasião do I Colóquio Internacional de Metafísica [2003], analisei as aproximações e as divergências entre a metafísica e a teorização psicanalítica chamada por Freud 
Metafísica e metapsicologia em cotnfronto: Aristóteles e Lacan no Seminário VII 113 de metapsicologia (MATTEO 2006, p. 321-330). Neste II Colóquio, o interlocutor privilegiado para esse confronto será Lacan, outro mestre pensador que estabeleceu com a filosofia inicialmente um diálogo produtivo, mas que se tornou progressivamente "tenso" a ponto de considerar-se, já no final da década de cinqüenta, um "antifilósofo", sugerindo que o discurso competente sobre subjetividade, antropologia, ética e cultura não é mais da filosofia e sim da psicanálise (ROUDINESCO, 1994, p. 262).

De sua vasta produção intelectual tomaremos como exemplo paradigmático para confrontar a metafísica com a metapsicologia o Seminário VII (1988) sobre a ética da psicanálise ministrado no ano letivo europeu 1959-60. Nele confronta a "novidade" da ética psicanalítica com alguns paradigmas éticos do Ocidente, tais como a ética do bem (Aristóteles), do dever (Kant), do útil (Bentham) e do amor (cristianismo). No momento, recorto apenas o paradigma eudaimonista e teleológico de Aristóteles, com destaque para os problemas da felicidade, do sumo bem, do desejo e do prazer.

Quanto ao significado fundamental dos dois termos chaves que queremos confrontar - metafísica e metapsicologia - é suficiente adotarmos a intuição inicial de Freud. Enquanto o "meta" de metafísica remete para cima ou para além do físico, o "meta" da metapsicologia reenvia a uma abordagem "científica" do que "se estende para além da consciência" (MASSON, 1986. p. 302). No caso de Lacan, a uma teorização rigorosa do inconsciente entendido na sua articulação com a linguagem.

Pode-se objetar que o confronto pretendido é impossível, na medida em que A ética a Nicômaco não é uma obra de metafísica. A epistemologia aristotélica, de fato, decorre de uma divisão da ciência conforme os objetos aos quais se dirige o logos humano. A metafísica é o saber referente ao mundo das coisas sempre idênticas a si mesmas (o mundo supralunar e os primeiros princípios), um saber que se sustenta sobre o "sempre" de uma ordem cósmica ou lógica. A ética, ao contrário, diz respeito às coisas humanas (ta antropina) sujeitas à deliberação e à opinião. É um saber que incide não sobre o sempre, mas o "muitas vezes" de um comportamento virtuoso, de uma ordem instituída e construída a partir de um esforço humano que tenta introduzir a regularidade do cosmos no caos da vida humana. Mesmo assim, penso que o confronto seja possível na medida em que as duas propostas éticas - a de Aristóteles e Lacan - se legitimam a partir de uma determinada antropologia claramente explicitada e de uma metafísica implícita que a sustenta. 


\section{A leitura lacaniana da ética aristotélica: uma visão geral}

É preciso que vocês percorram essa obra tão exemplar, nem que seja para medir a diferença

dos modos de pensamento que são os nossos

com aquele de uma das formas mais eminentes da reflexão ética

(LACAN, 1988, p. 20)

Essa afirmação de Lacan mostra que sua confrontação com Aristóteles não é inamistosa se levarmos a sério tanto sua estima pela obra Ética a Nicômaco, considerada entre as "mais exemplares e mais válidas" das que foram escritas até hoje, como o insistente aconselhamento aos seus ouvintes para ler essa obra qualificada de "apaixonante", "o primeiro livro verdadeiramente articulado, propriamente falando, em torno do problema ético" (LACAN, 1988. p. 49-50).

Referências diretas à clássica obra de Aristóteles se encontram especialmente na aula inaugural e nos primeiros encontros do Seminário VII. Não faltam, porém, referências à terminologia aristotélica nos encontros posteriores, tais como ergon, enérgueia ${ }^{1}$ o que mostra que - de alguma maneira - a ética aristotélica deixa o primeiro plano, mas não sai de cena. No entanto, mesmo reconhecendo que essa ética aristotélica "permanece para nós, rica de ressonâncias e de ensinamentos" e "seus esquemas não sejam inutilizáveis", não será nesses odres velhos que Lacan colocará o que chama de "nosso novo mel".2

Inicialmente, não pode deixar de assinalar uma similaridade da ética aristotélica com outros discursos éticos: a necessidade de remeter a uma ordem dentro da qual a reta conduta humana deve situar-se para ser considerada ética. No caso de Aristóteles, a conduta ordenada se expressa num ethos, num comportamento regular, numa ordem singular que deve inserir-se numa ordem mais ampla - social, política e cósmica - onde o Bem Supremo representa o "ponto de inserção, de vínculo, de convergência". ${ }^{3}$ Em suma, "macrocosmo e microcosmo estão supostos no princípio de toda a meditação aristotélica". ${ }^{4}$

Em seguida, adverte-nos que a ética aristotélica deve ser "historicizada", 5 o que naturalmente acarretará o reconhecimento de alguns

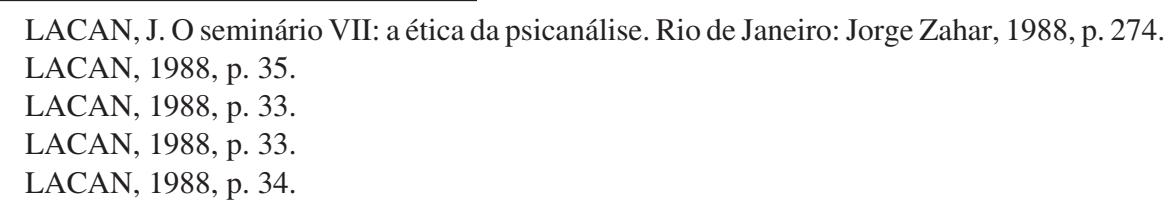

Rev. Filos., v. 19, n. 24, p. 111-129, jan./jun. 2007 
Metafísica e metapsicologia em cotnfronto: Aristóteles e Lacan no Seminário VII 115 limites. Primeiro, em Aristóteles, um certo "ideal humano" se articula em torno da figura do Senhor, do Mestre, melhor, de uma sociedade de mestres. Segundo, que - de modo semelhante a Deus - o ideal aristotélico é contemplativo. Terceiro, que essa experiência ética só é possível dentro de uma sociedade onde existia a possibilidade da "ociosidade". Diríamos com nossas palavras, ao sintetizar o pensamento de Lacan, que a ética aristotélica é fruto de uma sociedade escravocrata e refletirá nela mesma essa dicotomia e subordinação dos escravos aos homens livres, das paixões e dos desejos aos ditames da reta razão.

Será que nas sociedades contemporâneas, marcadas pela democracia política, uma compreensão mais positiva do trabalho e mais científica do mundo, houve também uma democratização da felicidade e do desejo a ponto de não mais nos definirmos apenas como seres de razão, mas também como seres de desejo?

Responder com certa objetividade a essas questões implica naturalmente um confronto mais pontual entre a ética aristotélica do sumo bem (eudaimonia) e da reta razão com aquela lacaniana do desejo e da falta do sumo bem para apaziguá-lo.

\section{O problema da felicidade, dos bens e do bem supremo em Aristóteles}

A problemática central ou a temática que dá unidade e coerência à Ética a Nicômaco é a tentativa de estabelecer uma relação entre bens humanos, a liberdade, a virtude e a eudaimonia entendida como o supremo bem e que se expressa no bem viver (eu zen) e bem agir (eu prattein) (ARISTÓTELES, 1979). Ponto de partida dessa primeira reflexão sistemática sobre a ética é a constatação de que toda ação e toda escolha visa um bem qualquer, que "o bem é aquilo a que todas as coisas tendem" e que há uma hierarquia de bens que se subordinam ao "sumo bem", ${ }^{6}$ isso é, ao que tanto o povo quanto os homens de cultura chamam de felicidade (Eudaimonia). ${ }^{7}$ Daí as duas principais características - teleologia e eudaimonia - com as quais é designada a ética aristotélica.

6 ARISTÓTELES. Ética a Nicômaco. In: Metafísica: ética a nicômaco poética. São Paulo: Abril Cultural, 1979, p. 49. (Os Pensadores).

7 ARISTÓTELES, 1979, p. 51.

Rev. Filos., v. 19, n. 24, p. 111-129, jan./jun. 2007 
Há divergências, porém, entre o povo e os sábios quanto à natureza da felicidade. Pode ser colocada no prazer e gozo de uma vida bestial; na honra da vida política; na riqueza de uma vida gananciosa; na eudaimonia de uma vida intelectual (contemplativa) e ética. ${ }^{8}$ Critica a ontologia platônica de um Bem transcendente e fundamenta sua ética na busca de bens humanos atingíveis e que dificilmente nos possam ser arrebatados. ${ }^{9}$ Além disso, sua ética não é excessivamente idealista ou intelectualista ao integrar vários elementos de uma concepção quase popular de felicidade. Há outros bens alguns necessários, outros cooperantes ${ }^{10}$ - para que a eudaimonia seja possível, tais como a amizade com seus diversos tipos, ${ }^{11}$ meios de fortuna, boa estirpe, boa prole, beleza física. ${ }^{12}$ Deve haver, porém, uma hierarquia dos bens. Entre os exteriores, os do corpo e os da alma, naturalmente são esses últimos que o filósofo privilegia. ${ }^{13}$

Reconhece que a consecução da eudaimonia é difícil. Afirma claramente que a bondade é rara, que não é fácil ser bom ${ }^{14}$ e que "uma vida virtuosa exige esforço e não consiste em divertimento". ${ }^{15}$ Implica a aquisição das virtudes "dianoéticas" pelo ensino-aprendizagem e das virtudes "éticas" pelo esforço pessoal até se tornarem um hábito, uma quase segunda natureza que leva o homem virtuoso a pautar suas ações de acordo com a reta razão.

O ideal desse homem "magnânimo", assim como é descrito na Ética a Nicômaco, só pode ser sonhado por reis, aristocratas e, especialmente, pelo filósofo por exercitar e cultivar a razão como os deuses e, dessa maneira, se tornar o preferido deles e presumivelmente também o mais feliz ${ }^{16}$. Tratase, portanto, de uma felicidade elitista. Dela estão excluídos os escravos e a massa dos não intelectuais (crianças, mulheres). $\mathrm{O}$ escravo pode ter acesso ao prazer, não à felicidade ${ }^{17}$. Assim também os meninos não podem ser felizes, ${ }^{18}$ como também não podem ser filósofos e físicos. ${ }^{19}$

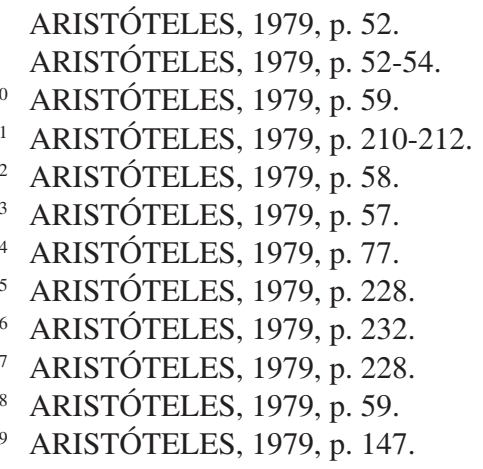


Metafísica e metapsicologia em cotnfronto: Aristóteles e Lacan no Seminário VII 117

Uma aproximação entre essa "vida boa" compartilhada com os amigos e o que Freud diz a respeito do amor pelos amigos e os filhos dos amigos, em $O$ mal-estar na Civilização, é possível e não escapou a $\operatorname{Lacan}^{20}$ ao afirmar: "Toda a concepção aristotélica dos bens está aí viva nesse homem verdadeiramente homem [Freud] e que nos diz as coisas mais sensíveis e mais sensatas sobre o que vale a pena partilhar com ele, esse bem que é o nosso amor". Lacan, porém, prefere acentuar as divergências com a eudaimonia aristotélica. A felicidade não é apenas difícil, é impossível.

\section{O problema da felicidade, dos bens e do bem supremo na psicanálise}

Se olharmos para o contexto cultural em que a psicanálise surge, é fácil identificar uma primeira grande fratura que se dá na cosmovisão da modernidade e que vai repercutir nessa concepção de felicidade e bem supremo de que falava Aristóteles. Primeiro, a felicidade, agora, por ter entrado na esfera da política não pode reduzir-se à solução aristotélica, na medida em que "não poderá haver satisfação de ninguém sem a satisfação de todos". ${ }^{21}$ Segundo, na compreensão de physis de Aristóteles, há uma relação direta entre fazer o bem e felicidade, fazer o mal e infelicidade. $\mathrm{O}$ bem supremo existe; seus sinais podem ser encontrados nos bens intermediários. Há uma ordem do mundo fiadora dessa aliança entre o bem e a felicidade. Está inscrito na Natureza (macrocosmo) e na psique do ser humano (microcosmo) um finalismo que leva a essa concordância ou que pelo menos a torna possível, uma teleologia regida por um Logos natural e universal, razão pela qual "todos os homens desejam o prazer porque todos aspiram à vida" (ARISTÓTELES, 1979).

O mundo supra e sublunar de Aristóteles porém foi literalmente pelos ares com a astronomia moderna. Inicia-se uma dessacralização do Cosmo, um "desencatamento do mundo", uma desconstrução de uma concepção hierárquica e harmônica dos seres, um divórcio, em certo sentido, entre o homem e o universo. Não é de estranhar, portanto, se Freud (1929) pode afirmar, em $O$ mal-estar na civilização e na seqüela de outros pensadores antes dele, que a felicidade não está inscrita na criação e o ser humano se encontra desamparado e impotente diante das três fontes de onde se origina o sofrimento: a fragilidade do próprio corpo, as forças não éticas da natureza, o próprio mundo da cultura.

20 LACAN, 1988, p. 277.

${ }^{21}$ LACAN, 1988, p. 350.

Rev. Filos., v. 19, n. 24, p. 111-129, jan./jun. 2007 
Essa falta de finalidade, essa insensibilidade cósmica diante de um frágil aparelho psíquico, que - como Freud descreve no Projeto (1895) tenta sobreviver se defendendo como pode (tela protetora) das intensidades da estimulação externa e das urgências da vida que pressionam de dentro, é possível reencontrá-la no conceito de pulsão (Trieb) como é descrito em Três ensaios sobre a teoria da sexualidade (1977), uma realidade que assenta em fontes somáticas, possui força, alvo (objetivo), mas não objetos definidos que possam satisfazê-la.

É verdade que certa leitura de Freud poderia levar a afirmar que, apesar de situar sua psicanálise na seqüela da revolução copernicana, pelo menos a área da sexualidade restaria ainda prisioneira da teleologia aristotélica na medida em que haveria inscrito no microcosmo de nosso psiquismo uma finalidade que escalona e hierarquiza as zonas erógenas em função da zona genital. Sob sua primazia, as fases anteriores (oral, anal e fálica) se unificariam e finalizariam. Conseqüentemente $o$ alvo da pulsão - sua satisfação - e o objeto que proporcionaria a satisfação (sexo oposto) pareceriam coincidir e encontrar certo repouso na objetalidade genital. Alvo, objeto e zona genital se unificariam para consecução de um fim: fazer de dois sexos opostos uma unidade. Nessa perspectiva, a ética da psicanálise não comportaria nenhuma novidade. Seria uma reatualização da antiga concepção de um mundo finalista regido por um bem supremo fiador de uma felicidade acessível ao ser humano.

Lacan se contrapõe a essa leitura. Reconhece que o próprio Freud ordena sua experiência em termos de gênese, de "desenvolvimento ideal", o que poderia nos levar a crer que, no fundo, a experiência psicanalítica parece não se diferenciar muito do que já foi dito anteriormente, isso é, que a criança é o pai do adulto. Mas o que é ser adulto? "Onde está o modelo do ser adulto?" - se pergunta Lacan. ${ }^{22}$ Sua crítica à genitalização do ideal do amor humano se funda precisamente no fato de que, ao lado dessa visão genética da sexualidade, há toda uma estrutura psíquica marcada pela intransponível oposição do princípio prazer-realidade e do processo primário-secundário. Uma oposição rearticulada ao longo de toda a obra freudiana e que evidencia que o mal-estar não é conjuntural, não depende apenas dos desarranjos da cultura. É estrutural.

Nesse sentido, a psicanálise se distanciou "de toda e qualquer formulação de disciplina da felicidade". ${ }^{23}$ É por isso que pode falar de certa dimensão trágica da ética psicanalítica na medida em que a demanda de felicidade do analisando não pode ser atendida pelo analista seja porque ele

22 LACAN, 1988, p. 37.

23 LACAN, 1988, p. 351.

Rev. Filos., v. 19, n. 24, p. 111-129, jan./jun. 2007 
Metafísica e metapsicologia em cotnfronto: Aristóteles e Lacan no Seminário VII 119 não possui o Bem Supremo, seja porque sabe que não existe. ${ }^{24} \mathrm{O}$ que ele possui e pode dar ao analisando é seu próprio desejo, um "desejo prevenido", que "não pode desejar o impossível". ${ }^{25}$

O fim da análise, inclusive didática, nos diz Lacan - não pode desaguar numa "racionalização moralizante", numa pretensa "harmonização psicológica", numa abolição da "antinomia", do "dilaceramento" de ser moral do homem submetido à instância moral do superego. É verdade que sempre é possível pensar a análise em função do que Lacan chama de serviço dos bens: "bens privados, bens de família, bens de casa, outros bens que igualmente nos solicitam, bens de ofício, da profissão, da Cidade". ${ }^{26}$ Isso não implica que a psicanálise possa se tornar fiadora de um "devaneio burguês". ${ }^{27}$ Analisar-se é confrontar-se com a intransponível condição humana, com a "desolação" e o "desamparo", com o desejo, cuja função "deve permanecer numa relação fundamental com a morte". ${ }^{28}$

Resta, agora, confrontar o discurso aristotélico e aquele lacaniano sobre dois significantes - desejo e prazer - estritamente correlacionados com o problema da felicidade.

\section{O problema do desejo e do prazer em Aristóteles}

Um dos problemas cruciais com o qual Aristóteles se defronta na construção de sua Ética é a concepção idealístico-socrática da virtude. Como é possível que alguém que "sabe", que tem "ciência" possa ser intemperante? Como o orthos logos, a reta razão, enquanto regra de uma ação ordenada, articula-se com algo como a intemperança? Essas perguntas apontam para um enigma que perpassa a reflexão ética pré-aristotélica: o da relação do desejo e do prazer com o bem, porque, em muitos casos, o primeiro se apresenta como algo que é "oposto ao esforço moral". ${ }^{29}$ Qual, afinal, o estatuto do desejo no âmbito da antropologia aristotélica em geral e da ação moral em particular, visto que os desejos que não obedecem à razão, os "desejos bestiais" não entram na esfera ética, estão excluídos, portanto, da realização do homem? $?^{30}$

24 LACAN, 1988, p. 359.

25 LACAN, 1988, p. 360.

26 LACAN, 1988, p. 363.

LACAN, 1988, p. 364.

LACAN, 1988, p. 364.

LACAN, 1988, p. 49.

LACAN, 1988, p. 23.

Rev. Filos., v. 19, n. 24, p. 111-129, jan./jun. 2007 
Não vamos retomar a problemática do desejo no mundo grego em geral e acompanhar a evolução da concepção aristotélica da fase platônica até sua última reformulação filosófica (ROCHA, 1999, 2000a, 2000b). No momento nos interessa mais determinar como o desejo se articula com a antropologia filosófica aristotélica.

Uma ética que pretenda, de fato, justificar suas eventuais prescrições ou orientações de comportamento se apóia geralmente numa determinada antropologia. Agere sequitur esse. O agir segue o ser ou deveria ser conforme a natureza do agente. Para compreender as divergências entre a ética aristotélica e aquela psicanalítica, é necessário focalizar a descrição da estrutura e funcionamento do que Aristóteles chama $\Psi v \chi \eta$ (psyche) e Freud de aparelho psíquico. Na realidade, em ambos os casos seria mais correto em se falar de "descrições" do psiquismo. Como em Freud há uma primeira e

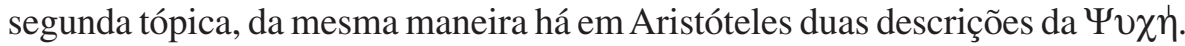
A primeira, dualista, dividida numa parte racional ( $\lambda$ o $\gamma \tau \kappa o v)$ e outra irracional

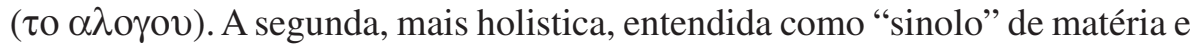
forma na última fase de seu pensamento.

No caso de A Ética a Nicômaco, a antropologia subjacente é aquela que corresponde à chamada fase organicista ou biologizante da alma, quando Aristóteles já tinha elaborado sua antropologia própria, distante daquela platônica (ARISTÓTELES, 1979).

Há uma parte da $\Psi v \chi \eta$ que obedece a uma regra (kata logon, racional) e outra irracional (alogon), subdividindo-se em vegetativa ( $\tau$ o $\theta \rho \varepsilon \pi \tau \iota \kappa o v$, totalmente irracional e incapaz de qualquer virtude humana) e em

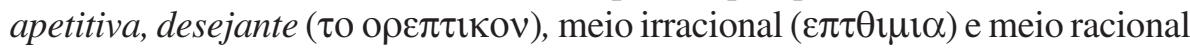
( $\beta$ ov $\lambda \eta \zeta i \zeta)$, na medida em que certos desejos podem entrar na esfera da racionalidade - e portanto da ética - na medida em que escutam e obedecem ao princípio racional. ${ }^{31}$

Esse jogo de linguagem pode ser enriquecido com o termo o $\rho \xi \xi \zeta$, para indicar o desejo em geral e o termo $\theta v \mu$ o $\zeta$ para designar os desejos que a tradicão grega chamou de dimensão "irascível”, de arrebatamento, de indignação, de impulsividade, de transbordamento colérico que tanto pode entrar no domínio da razão quanto nos levar ao descontrole. Quanto à parte racional

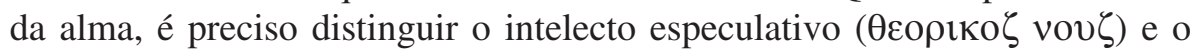
intelecto pratico $(\pi \rho \alpha \kappa \tau \imath \kappa о \zeta \vee 0 v \zeta)$, esse diretamente envolvido na ordem do agir etico na medida em que está na origem da ação ao representar (por meio

31 ARISTÓTELES, 1979, p. 64.

Rev. Filos., v. 19, n. 24, p. 111-129, jan./jun. 2007 
Metafísica e metapsicologia em cotnfronto: Aristóteles e Lacan no Seminário VII 121

de representações, imagens) ao sujeito agente determinado objeto como um bem, o que o torna desejável. Para Aristóteles, de fato, não se deseja se não o que se julga ser um bem (Metafísica, 1979, Livro VII, p. 1072). Algo é desejável porque é um bem e não vice-versa. A função ou faculdade desejante da alma, portanto, pode não ter a primazia lógica, mas é o motor da ação. $O$ desejo não é visto como carência, mas como "força", "potência" ( $\delta v v \alpha \mu \imath \zeta)$ que influencia poderosamente a acão humana, tanto rumo a uma vida virtuosa como a uma vida intemperante e incontinente.

À divisão da dimensão racional da alma corresponde a divisão das virtudes: as do entendimento (dianoéticas) e as de caráter (éticas) (ARISTÓTELES, 1979). Há igualmente uma correspondência entre a hierarquia das funções da alma e a ordem das virtudes: superioridade da vida contemplativa sobre a ativa. Esse domínio do espírito, porém, não implica, para Aristóteles, a negação do desejo. Sua concepção de virtude sobreassume a razão desejante na esfera da phronesis (sabedoria prática). A polêmica com Sócrates permite a Aristóteles ultrapassar certa visão maniqueísta da vida moral situada nos extremos da virtude e do vício. Não há apenas essas duas alternativas morais. Existem níveis de moralidade. Para a maioria das pessoas restam caminhos intermediários entre a vida dos deuses (virtude divina) e a dos animais (bestialidade viciosa ou doentia). A experiência mostra que tanto a virtude quanto o vício são coisas raras. Para a grande maioria, Aristóteles aponta um ideal mais acessível: perseguir a continência e evitar a incontinência. A primeira nos eleva acima da massa; a segunda nos arrasta abaixo do vulgar.

Coerente com essa visão menos extremada de vida ética é o discurso aristotélico sobre o prazer. Na época, o debate sobre esse tema opunha duas correntes: de um lado, os defensores do prazer (Demócrito, Aristipo, Eudoxio), justificando certa vida de prazer como uma vida humana e mesmo filosófica. Do outro, seus adversários (Antístenes, em parte o próprio Platão, Espeusipo), desautorizando a legitimidade de qualquer prazer, não apenas os mais vulgares, mas o prazer em si mesmo. O posicionamento de Aristóteles a respeito dessa polêmica se encontra em dois tratados situados no: final do Livro VII (n. 11-14) e no Livro X da Ética a Nicômaco (n.1-5). O primeiro é anterior e pertence à Ética a Eudemo, ao primeiro curso de moral que Aristóteles ministrou na Ásia Menor. O segundo pertence ao curso de moral que reescreveu nos primeiros anos da fundação do Liceu.

No primeiro tratado, Aristóteles retoma a tese de que todo prazer é um bem. A prova positiva consiste na constatação de que todo mundo concorda que a dor é um mal que deve ser evitado. Logo, o contrário da dor, que é o 
prazer, é um bem e deve ser procurado. Os indícios que corroboram sua argumentação se mostram no fato de que todos os seres (animais e homens) buscam o prazer. É verdade que nem todos buscam o mesmo prazer, todos, porém, buscam "o" prazer pressentido como um bem supremo. A maioria coloca o sumo bem nos prazeres corporais porque são os mais procurados, os mais acessíveis a todos e porque a massa desconhece outros prazeres.

A consequiência lógica dessa primeira concepção de prazer é que, então, a felicidade consiste no prazer. Para não cair nessa armadilha, no segundo tratado, identifica o prazer como conseqüência necessária da atividade perfeita, uma espécie de epifenômeno da atividade digna. Resumindo as várias opiniões sobre prazer e dor, afirma que "parece claro [...] que nem o prazer é o bem, nem todo prazer é desejável, e que alguns prazeres são realmente desejáveis por si mesmo". ${ }^{32}$ Há, portanto, uma clara disjunção entre prazer e bem ou pelo menos entre determinados prazeres. No entanto, apesar das mudanças na abordagem do tema no segundo tratado, o que permanece é que um certo prazer é o bem supremo, isso é, o prazer de contemplar ou a atividade contemplativa. Pouco parece importar se tenhamos que identificá-lo com a própria atividade ou como corolário dela.

\section{O problema do desejo e do prazer na psicanálise freudo- lacaniana}

Estabelecer um confronto entre o desejo em Aristóteles e na psicanálise esbarra numa série de dificuldades:

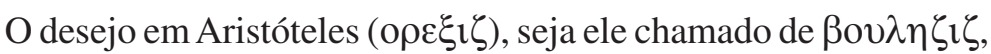
$\varepsilon \pi \imath \theta \imath \mu \alpha, \theta v \mu o \zeta$ gravita e é definido a partir do significante-chave de

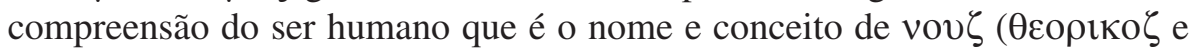
$\pi \rho \alpha \kappa \tau \iota \kappa о \zeta)$, a função propriamente humana da Psiché. Na psicanálise freudiana e especialmente lacaniana, a realidade do desejo assume um estatuto peculiar a ponto de Lacan considerá-lo "o essencial da psicanálise", "um objeto absoluto" (Circular da Escola Freudiana de Paris de 19/9/1964, apud ROUDINESO, 1994). Entramos num outro jogo de linguagem. Outros significantes gravitam em torno do desejo, tais como: instinto, pulsão, prazer, vontade, deleite, gozo, demanda. Esses significantes não são, sem mais nem menos, intercambiáveis nem entre si (Cf. HANNS, 1996) e muito menos com os do universo teórico aristotélico. Mesmo que, grosso modo, pudessem remeter a uma mesma realidade humana 32 ARISTÓTELES, 1979, p. 222. 
Metafísica e metapsicologia em cotnfronto: Aristóteles e Lacan no Seminário VII 123

ou experiência, vivência como queira se chamar o apaziguamento da tensão e a busca de satisfação, os diferentes contextos teóricos em que os termos devem ser colocados os tornam praticamente incomensuráveis.

Não é preciso lembrar que o tratado de Ética de Aristóteles é dirigido ao homem adulto, visto que os jovens - quanto mais as crianças! carecem de sabedoria prática e de experiência, a qual só o tempo pode dar (ARISTÓTELES, 1979). Além disso, os jovens tendem a seguir suas paixões e o estudo da ética seria inútil visto que o objetivo não é o conhecimento, mas a ação. ${ }^{33}$ Enquanto, portanto, Aristóteles nos descreve o conflito desejo-razão como pode ocorrer no homem adulto, a psicanálise situa essa problemática do desejo desde o nascimento.

Outra diferença fundamental com o desejo em Aristóteles é que a experiência psicanalítica e sua tradução metapsicológica nos falam do desejo humano não em termos gerais e universais, mas como algo de singular, uma experiência irredutível, arcaica, primitiva, infantil, irrealista que de universal tem apenas o fato de que "essa particularidade se encontre em cada um dos seres humanos" (LACAN, 1988). Em Freud - segundo Lacan - o orthos logos não remete a "proposições universais". O que se articula no inconsciente "é o discurso que se atém ao nível do princípio do prazer". O princípio de realidade entra em ação para que se chegue a uma ação possível, visando o "orthos entre aspas de ironia". ${ }^{4}$

Segundo Lacan, foi Freud que mostrou ao homem a impossibilidade de alcançar seu próprio desejo, de não mais encontrar seu objeto, de ficar apenas com a infelicidade dessa procura, pois a natureza do desejo não é uma coisa "simples", nem "elementar", nem "animal", nem "inferior", nem propriamente de ser "pleno de sentido", "arquétipo", "algo de natural" ou "genético", mas é da ordem do inconsciente (LACAN, 2005).

A revolução operada por Freud no âmbito da moral consiste em mostrar que - "no nível do princípio do prazer não há Bem Supremo, que o Bem Supremo, que é das Ding, que é a mãe, o objeto de incesto, é um bem proibido e que não há outro bem" (LACAN, 1988, p. 90).

Devemos a Lacan uma distinção fundamental do desejo de outros significante correlatos. O desejo está além do instinto e aquém da demanda, nada mais é do que a metonímia do discurso da demanda". ${ }^{35}$ É o que suporta essa metonímia, mas não se confunde com a demanda, pois "realizar seu desejo

ARISTÓTELES, 1979, p. 50.

LACAN, 1988, p. 43.

LACAN, 1988, p. 352.

Rev. Filos., v. 19, n. 24, p. 111-129, jan./jun. 2007 
coloca-se sempre numa perspectiva de condição absoluta [...], numa perspectiva de Juízo final", ${ }^{36}$ numa relação do homem com sua própria morte "na medida em que é desejo de nada, relação do homem com sua falta a ser [...]". ${ }^{37}$

É nesse sentido que a personagem Antígona é interpretada por Lacan como a personificação do desejo puro, uma heroína não a serviço dos deuses ou das leis não escritas, mas de sua paixão pelo irmão Polinice. Ao desvincular do irmão as contingências de seu drama histórico e considerá-lo na sua pureza, Antígona estabelece o limite intransponível em nome do qual está disposta a morrer. Assume, dessa maneira, seu destino paradoxal. Tornase uma "vítima tão terrivelmente voluntária" ${ }^{38}$ marcada pela "morte invadindo o domínio da vida, a vida invadindo a morte" 39 . É nessa zona, nos diz Lacan, que o raio do desejo se reflete e ao mesmo tempo se retrai, proporcionando "esse efeito tão singular, o mais profundo, que é o efeito do belo no desejo", ${ }^{40}$ um efeito com "duas faces", ao mesmo tempo apaziguador pela apreensão da beleza e ofuscante pela revelação da inacessibilidade desse aspecto absoluto do desejo, temperado, mas não eliminado na medida em que nenhum objeto pode detê-lo.

Quanto à problemática do prazer, $\operatorname{Lacan}^{41}$ reconhece que tanto Freud como Aristóteles a colocam no centro de sua reflexão ética, porém indaga: "Será que se trata da mesma função do prazer numa e noutra elaboração?". A resposta a essa questão lhe permite demarcar as diferenças e destacar a originalidade e novidade das contribuições psicanalíticas na compreensão do desejo e do prazer.

Tanto no Projeto quanto na evolução da metapsicologia freudiana, Lacan encontra "o rastro de uma elaboração que reflete um pensamento ético". ${ }^{42}$ O conflito neurótico é desde o início um conflito "massivamente de ordem moral". ${ }^{43}$ A oposição princípio do prazer x princípio de realidade, processo primário x processo secundário é "menos da ordem da psicologia do que da ordem da experiência propriamente ética". ${ }^{44}$ Nesse sentido, afirma Lacan, ${ }^{45}$

36 LACAN, 1988, p. 353.

LACAN, 1988, p. 357.

LACAN, 1988, p. 300.

LACAN, 1988, p. 301.

LACAN, 1988, p. 302.

LACAN, 1988, p. 21.

LACAN, 1988, p. 51.

LACAN, 1988, p. 49.

LACAN, 1988, p. 49.

5 LACAN, 1988, p. 40.

Rev. Filos., v. 19, n. 24, p. 111-129, jan./jun. 2007 
Metafísica e metapsicologia em cotnfronto: Aristóteles e Lacan no Seminário VII 125

"Nunca ninguém, nunca nenhum sistema de reconstituição da ação humana fora tão longe na acentuação desse caráter fundamentalmente conflituoso".

O princípio do prazer assim como aparece no Projeto é mais um princípio de inércia. Estamos diante de um aparelho neurológico cuja tendência é o engodo e o erro, ${ }^{46}$ visto que fundamentalmente busca a satisfação de suas necessidades mais pela via alucinatória. O princípio de realidade exerce uma função corretiva, mas o acesso à realidade não é fácil, é precário e os sentimentos que se apresentam como guias para o real são enganadores. ${ }^{47}$

A realidade psíquica, portanto, é constituída por um duplo processo: um, de ficção, ligado à atividade alucinatória e ao princípio de prazer; o outro, de pensamento para realizar a ação específica que, efetivamente, consiga aliviar a tensão interna. No registro do processo primário, o princípio do prazer identifica o bem com o prazer. Essa é a razão, segundo Lacan, pela qual os éticos de todos os tempos atrelaram esses dois termos - prazer e bem - "tão fundamentalmente antinômicos". ${ }^{48}$ No registro do processo secundário, o princípio de realidade aponta para uma "figura problemática". A adequação à realidade não implica uma adequação a um bem qualquer. É por isso que a psicanálise lacaniana se insurge contra uma determinada concepção de "cura" psicanalítica que privilegiaria o eu autônomo e uma conseqüente função adaptativa. Quer devolver à psicanálise o caráter revolucionário que enxerga nos textos freudianos. Nesse sentido, interpreta uma eventual "ascese" freudiana mais como uma "descida" ao traduzir a famosa frase de Freud (1977, p. 102) "onde estava o id, ali estará o ego" da seguinte maneira: "Ali onde isso era, eu devo advir" (ROUDINESCO, 1998). Isso implica que, mais do que obedecer ao imperativo categórico do superego, devemos nos orientar pela bússola psicanalítica que aponta para o desejo inconsciente, o que não implica propor "um retorno a nossos instintos como medida de nossa ação" 49 e sim um retorno ao sentido da ação. É isso que está subjacente à hipótese freudiana do inconsciente, isso é, que a ação do homem tem um sentido escondido que remete ao nosso desejo. Por isso, a psicanálise "escolhe como padrão de revisão da ética [...] a relação da ação com o desejo que a habita" e nos convida a não abrir mão de nosso próprio desejo. ${ }^{50}$

46 LACAN, 1988, p. 40.

47 LACAN, 1988, p. 43.

48 LACAN, 1988, p. 47.

49 ROUDINESCO, E.; PLOM, M. Dicionário de psicanálise. Rio de Janeiro: Zahar, 1998, p. 374.

50 ROUDINESCO, 1998, p. 375. 
Ao privilegiar o pólo do desejo e não o do superego, estaria Lacan nos propondo uma ética da perversão? Evidentemente que não. Para compreendermos o porquê, vamos resumir as idéias apresentadas e concluir.

\section{Resumindo e concluindo}

Partimos de uma constatação: os significantes metafísica e metapsicologia insinuam que, por certos aspectos, os dois termos podem insinuar certa proximidade semântica, mas, por outros, apontam para diferenças radicais.

Ao analisarmos o discurso filosófico aristotélico e aquele lacaniano sobre Ética, com destaque para o problema da felicidade, do desejo e do prazer, procuramos identificar os "jogos de linguagem" que os sustentam. Penso que ambos devam ser respeitados em sua autonomia e alteridade, mas evidentemente como não há metafísica desconectada de uma epistemologia, de uma física e de uma antropologia, assim também é impossível um discurso metapsicológico que não se situe sempre dentro de um horizonte metafísico, de pressupostos teóricos nem sempre tematizados (HEIDEGGER, 2001).

A vantagem da metapsicológica sobre a metafísica é que a primeira não tem a pretensão de ocupar o lugar da verdade. Ao contentar-se com a "meiaverdade" que é acessível ao homem permanece uma teorização, uma construção especulativa que - mesmo não arbitrária - desempenha apenas uma função eurística. Seus enunciados não são fundantes, não remetem a uma ontologia, são descartáveis. Nesse sentido, o próprio Lacan nos surpreende positivamente no Seminário VII ao dizer o seguinte a respeito de seu ensino: "quer se trate do simbólico, do significante ou do desejo, nenhum desses termos, no fim de contas, jamais poderá servir, pelo meu procedimento, de amuleto intelectual para quem quer que seja", ${ }^{51}$ manifestando com isso sua desautorização, para que o sufixo ismo fosse acrescentado a seu ensino.

Não se trata, portanto, de pura e simplesmente repetir aforismos e conceitos lacanianos e sim de utilizá-los como estímulos ao nosso pensamento. Nesse sentido, penso que o melhor de Lacan, ao articular ou desarticular desejo e sumo bem (felicidade), mostra-nos uma dialética negativa entre Desejo e Lei que é impossível suprassumir e que não se deixa absorver por apenas um dos dois pólos.

51 LACAN, 1988, p. 305.

Rev. Filos., v. 19, n. 24, p. 111-129, jan./jun. 2007 
Metafísica e metapsicologia em cotnfronto: Aristóteles e Lacan no Seminário VII 127

Não tem sentido, portanto, contrapor de um lado Aristóteles com sua reta razão, e, do outro, Lacan com a defesa intransigente do desejo. Se Deus está morto, nos diz Lacan, nem por isso o homem se livrou da lei e da culpa. De uma forma paradoxal repete: se Deus está morto, nada mais nos é permitido. Quanto mais o desejo se torna imperioso e livre, tanto mais a interdição é necessária (LACAN, 2005). O mito freudiano, que nos fala do assassinado do pai da horda primeva, não liberta o homem da figura, da função, do nome do pai, mas evidencia que a interdição que se abate sobre o desejo é estrutural. O declínio do complexo de Édipo, o luto do Pai tem como sequiela o surgimento do superego.

Em outras palavras, parece-me que Lacan nos reenvia a mensagem contida na Tragédia de Sófocles Antígona da qual nos deu uma interpretação original. Cada um de nós tem algo a ver com o infortúnio, a desgraça (Ate) de Antígona, com um destino, uma história e uma pré-história que nos precedem e marcam. Cada um de nós está assujeitado a um inconsciente (estruturado como linguagem), às pulsões, ao desejo, à falta que nos habita, o que inviabiliza qualquer projeto humano que vise uma harmonização interior e social que atenda pelo nome de felicidade. O que não implica, naturalmente, total impotência e necessária resignação. Se somos vítimas, somos também - como Antígona e Creonte - "vítimas voluntárias" e nesse "voluntário" abriga-se não apenas a "servidão voluntária" (LA BOETIE, 2003) e o "pacto masoquista" (BIRMAN, 2006), mas também a esperança humana num mundo pessoal e comunitário melhor, onde desejo e bem-estar possam de alguma maneira se coadunar, mesmo que precariamente, não apenas como possibilidade aberta a alguns poucos homens "magnânimos", mas como conquista democrática efetiva e historicamente viável.

\section{Referências}

ARISTÓTELES. Ética a Nicômaco. In: . Metafísica: ética a nicômaco poética. São Paulo: Abril Cultural, 1979. (Os Pensadores)

BIRMAN, Joel. A servidão. In: Arquivos do mal-estar e da resistência. Rio de Janeiro: Civilização Brasileira, 2006. p.17-32.

DEGUY, M. (Org.). Lacan avec lês philosophes. Paris: Albin Michel, 1992

FREUD, S. Correspondência de amor e outras cartas, 1873-1930. Rio de Janeiro: Nova Fronteira, 1982. 
standard brasileira das obras psicológicas completas de Sigmund Freud. 2. ed. Rio de Janeiro: Imago, 1977. v. 1.

Três Ensaios sobre a sexualidade. [1905]. In: . Edição standard brasileira das obras psicológicas completas de Sigmund Freud. 2. ed. Rio de Janeiro: Imago, 1977. v. 7.

O mal-estar na Civilização. [1929]. In: Edição standard brasileira das obras psicológicas completas de Sigmund Freud. 2. ed. Rio de Janeiro: Imago, 1977. v. 21.

A dissecação da personalidade psíquica [1932]. In: Edição standard brasileira das obras psicológicas completas de Sigmund Freud. 2. ed. Rio de Janeiro: Imago, 1977. v. 22.

JURANVILLE, A. Lacan e a filosofia. Rio de Janeiro: Jorge Zahar, 1979.

HANNS, Luiz. Dicionário comentado do alemão de Freud. Rio de Janeiro: Imago, 1996.

HEIDEGGER, M. Seminários de Zollikon. São Paulo: Vozes, 2001.

LACAN, J. O seminário VII: a ética da psicanálise. Rio de Janeiro: Jorge Zahar, 1988.

O triunfo da religião, precedido de, discurso aos católicos. Rio de Janeiro: Jorge Zahar, 2005.

LA BOÉTIE, E. De. Discurso da servidão voluntária. São Paulo: RT, 2003.

MASSON, J. A correspondência completa de Sigmund Freud para Wilhelm Fliess. Rio de Janeiro: Imago, 1986, p. 302.

MATTEO, Vincenzo Di. O sujeito freudiano entre Metapsicologia e Metafísica. In: BONACCINI, J. A. et al. (Org). Metafísica: história e problemas. Natal: EDUFRN, 2006, p. 321-330.

ROUDINESCO, E.; PLOM, M. Dicionário de psicanálise. Rio de Janeiro: Zahar, 1998.

Jacques Lacan: esboço de uma vida, história de um sistema de pensamento. São Paulo: Companhia das Letras, 1994. 
Metafísica e metapsicologia em cotnfronto: Aristóteles e Lacan no Seminário VII 129

ROCHA, Zeferino. O desejo na Grécia Arcaica. Revista Latinoamericana de Psicopatologia Fundamental, v. 1, n. 4, p. 94-122, dez. 1999.

O desejo na Grécia Clássica. Revista Latinoamericana de Psicopatologia Fundamental, v. 2, n. 1, p. 84-116, mar. 2000a.

O desejo na Grécia Helenística. Revista Latinoamericana de Psicopatologia Fundamental, v. 3, n. 2, p. 98-128, jun. 2000 b.

SAFATLE, Vladimir (Org.). Um limite tenso: Lacan entre a filosofia e a psicanálise. São Paulo: UNESP, 2003.

Recebido em/Received in: 07/03/2007 Aprovado em/Approved in: 21/03/2007 
